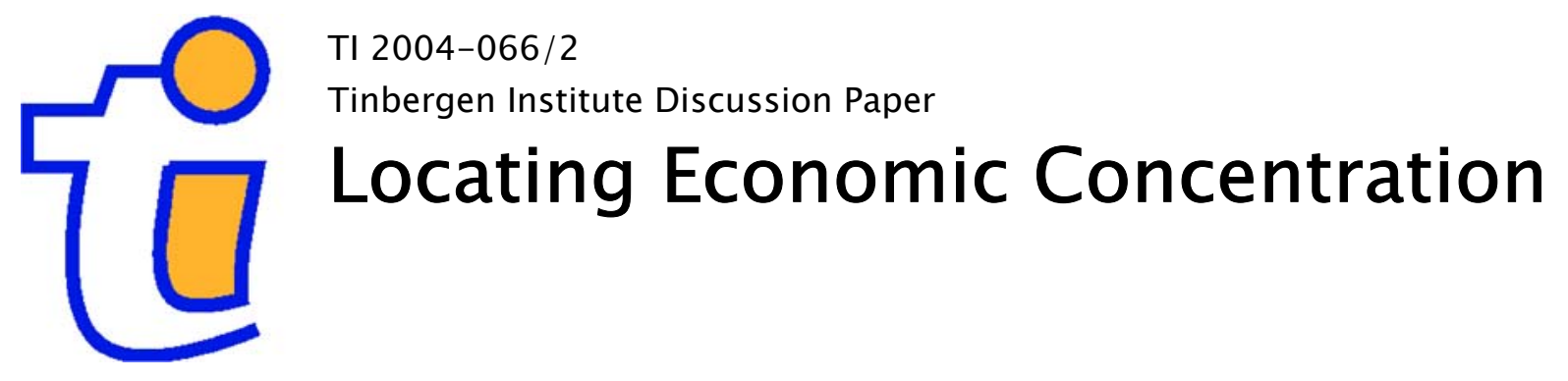

Jeroen Hinloopen 1,3

Charles van Marrewijk $k^{2,3}$

' Faculty of Economics and Econometrics, Universiteit van Amsterdam, and Economics Network for Competition and Regulation (ENCORE),

2 Faculty of Economics, Erasmus Universiteit Rotterdam,

3 Tinbergen Institute. 


\section{Tinbergen Institute}

The Tinbergen Institute is the institute for economic research of the Erasmus Universiteit Rotterdam, Universiteit van Amsterdam, and Vrije Universiteit Amsterdam.

Tinbergen Institute Amsterdam

Roetersstraat 31

1018 WB Amsterdam

The Netherlands

Tel.: $\quad+31(0) 205513500$

Fax: $\quad+31(0) 205513555$

Tinbergen Institute Rotterdam

Burg. Oudlaan 50

3062 PA Rotterdam

The Netherlands

Tel.: $\quad+31(0) 104088900$

Fax: $\quad+31(0) 104089031$

Please send questions and/or remarks of nonscientific nature to driessen@tinbergen.nl.

Most TI discussion papers can be downloaded at http://www.tinbergen.nl. 


\title{
Locating economic concentration ${ }^{1}$
}

\author{
JEROEN HINLOOPEN ${ }^{2}$ \\ University of Amsterdam, Tinbergen Institute, and \\ Economics Network for Competition and Regulation (ENCORE) \\ and \\ CHARLES VAN MARREWIJK ${ }^{3}$ \\ Erasmus University Rotterdam and Tinbergen Institute
}

June 2004

\begin{abstract}
We analyze the distribution of economic activity across space for different types of activity and different levels of aggregation. Not only is this distribution highly uneven (independently of the type of activity and level of aggregation), it is also remarkably regular regarding its size distribution (rank-size rule or Zipf's Law) and regarding its interaction (gravity equation).
\end{abstract}

Keywords: economic activity, distribution, rank-size rule, Zipf's Law, and gravity equation

JEL codes: F0, O0, R0

\footnotetext{
${ }^{1}$ This article will be published in Brakman and Garretsen, eds. (2005). We would like to thank Steven Brakman, Harry Garretsen, and the participant at the 2003 annual meeting of the Royal Dutch Economic Association for useful comments and suggestions. The usual disclaimer applies.

${ }^{2}$ Correspondence: University of Amsterdam, Department of Economics, Roetersstraat 11, 1018 WB Amsterdam; J.Hinloopen @ uva.nl; www.fee.uva.nl/io/jhinloopen.

${ }^{3}$ Correspondence: Erasmus University Rotterdam, Department of Economics, P.O. Box 1738, 3000 DR Rotterdam; vanmarrewijk@few.eur.nl; www.few.eur.nl/few/people/vanmarrewijk.
} 


\section{Introduction}

We were asked by Steven Brakman and Harry Garretsen for a contribution to this volume with the primary objective "to show that economic activity is not uniformly distributed across space." Although the editors also asked us several other research questions which we will address in the sequel, the reader's first reaction to the primary objective may be: "but of course economic activity is not homogenously distributed across space, everyone knows that!" An Australian 'walkabout' in the bush will give an entirely different picture of 'economic activity' than an attempt to cross the center of Manila during rush hour. Evidently, the distribution of economic activity is uneven. Nonetheless, the reader's potential first reaction regarding the obviously uneven distribution of economic activity is unjustified for at least three reasons.

First, we have to be precise in what we mean with economic activity. Obviously, these are activities involving people, so a first indication of the distribution of economic activity can be given by looking at the distribution of people across the globe. As a result of differences in education, available capital, quality of infrastructure and communication, however, there are enormous differences in productivity between people, leading to huge differences in value added per capita, to be taken into consideration in analyzing the distribution of economic activity. In turn, this correction for productivity differences should not be pushed too far as it is positively correlated with the local price level, for which we then should also correct. This brings us to purchasing power corrected value added as probably the most suitable empirical measure of economic activity.

Second, we have to take the level of aggregation into consideration, both in terms of geography and economic activity. The geographic level of aggregation may focus on global regions as defined by the World Bank (see below), on countries, on regions within countries, on cities, and even on areas within cities. The economic level of aggregation focuses on a specific type of economic activity. This might be all produced goods and services ${ }^{4}$, a specific category (such as agriculture or services), or an analysis of just one or only a few types of goods (such as the flower or the movie industry).

Third, we can analyze if there are regularities in the (un)even distribution of economic activity or in the interaction between centers of economic activity. We then go beyond the affirmation that economic activity is not evenly distributed across space, to try to find a pattern in this distribution. If there is such a pattern, we would of course like an explanation for it. This

\footnotetext{
${ }^{4}$ The term 'goods' also refers to services .
} 
explanation, in turn, can be of the 'first nature' type (exogenous in character: the wood industry is usually located in areas with lots of trees; big harbors are usually at the mouth of a navigable river) or the 'second nature' type (endogenous in character: computer activity is located in Silicon Valley to benefit from local knowledge spillovers; there are many hot dog stands in New York because there are many people). Insights in these explanations can result in proper policy advice. This chapter analyzes the structure and distribution of economic activity, but not the possible explanations for this distribution or the concomitant policy recommendations. The latter two issues are addressed in the other articles in this volume, notably by de Mooij, Gorter, and Nahuis (location decisions), Lambooij and van Oort (agglomeration powers), and Oosterhaven and Rietveld (transport costs and infrastructure).

As there is a sheer endless series of possible combinations that we could analyze regarding type of economic activity, distribution, economic and geographic aggregation, and interaction, it is remarkable that a few clear and simple conclusions regarding the distribution and interaction of economic activity can be drawn nonetheless, as summarized in the following five stylized facts:

- There is an uneven distribution regardless of the type of economic activity.

- There is an uneven distribution regardless of the geographic level of aggregation.

- There is an uneven distribution regardless of the economic level of aggregation.

- There is a remarkable regularity in the spatial distribution of economic activity.

- There is a remarkable regularity in the interaction between economic centers.

\section{Global regions ${ }^{5}$}

There are many countries in the world. The World Bank distinguishes 207 different countries on its CD-Rom, many of which are so small that you may not know them (Palau? Kiribati?). Because China considers it a province, Taiwan is the only important country not included as a separate entity, although it is included in various groups of countries. The next section analyzes difference between countries. This section characterizes groups of countries based on the World Bank's grouping in global regions (see the appendix for details):

1. EAP: East Asia and Pacific (includes China and Indonesia)

2. ECA: (East) Europe and Central Asia (includes Turkey and Russia)

3. HIC: High Income Countries (includes Western Europe, USA, and Japan)

4. LAC: Latin America and Caribbean (includes Brazil and Mexico)

5. MNA: Middle East and North Africa (includes Egypt)

\footnotetext{
${ }^{5}$ Unless otherwise indicated, all data in sections 2-4 are for the year 2000 and taken from the World Development Indicators CD-ROM 2002. Rural population density data are for the year 1999.
} 
6. SAS: South Asia (includes India)

7. SSA: Sub-Sahara Africa (includes Nigeria and South Africa)

With the exception of the high income countries (HIC), these are geographically coherent entities, although the World Bank classification is also based on social, political, economic, and historical factors. ${ }^{6}$ Table 1 provides basic information regarding population, area, and production for these global regions.

Table 1 Basic information for global regions (2000)

\begin{tabular}{l|rrrrrrr|r}
\hline \hline & EAP & ECA & HIC & LAC & MNA & SAS & SSA & World \\
\hline Population & 1,855 & 474 & 903 & 516 & 295 & 1,355 & 659 & 6,057 \\
Area & 16,0 & 23,8 & 30,9 & 20,1 & 11,0 & 4,8 & 23,6 & 130,1 \\
GNP & 2,027 & 927 & 24,945 & 1,922 & 651 & 591 & 303 & 31,351 \\
GNP ppp & 7,609 & 3,140 & 24,793 & 3,624 & 1,545 & 2,984 & 1,044 & 44,459 \\
\hline Population density & 116 & 20 & 29 & 26 & 27 & 283 & 28 & 47 \\
GNP density & 127 & 39 & 807 & 96 & 59 & 124 & 13 & 241 \\
GNP ppp density & 476 & 132 & 802 & 181 & 141 & 624 & 44 & 342 \\
\hline
\end{tabular}

Area in million $\mathrm{km}^{2}$; population in millions; GNP = Gross National Product in $\$$ billion; ppp = purchasing power parity; GNP ppp in $\$$ billion; population density in people per $\mathrm{km}^{2}$; GNP and GNP ppp density in $\$$ 1000 per km${ }^{2}$; data are for 2000

According to the United Nations there are more than six billion people on our planet since 12 October 1999, a doubling in about 40 years. $^{7}$ Almost a third of these six billion live in SouthEast Asia (EAP; 1,85 billion), more than six times as many as the 295 million people in the Middle East and North Africa (MNA). The other global regions are within these two extremes. Obviously, these absolute numbers give no indication regarding the distribution of the population as the global regions also differ in size, ranging from 30.9 million $\mathrm{km}^{2}$ for the high income countries (HIC) to 4.8 million $\mathrm{km}^{2}$ for South Asia (SAS). The earth's total area is about 130 million $\mathrm{km}^{2}$, indicating that there are on average about 47 people per $\mathrm{km}^{2}$. As there is a negative correlation at this level of aggregation between size and population, the population density (people per $\mathrm{km}^{2}$ ) is more unevenly distributed than the absolute population levels. The highest density (283) is reached in South Asia (SAS), more than 14 times higher than the lowest density (20) of (East) Europe and Central Asia (ECA).

\footnotetext{
${ }^{6}$ Sometimes a sub-grouping of high income countries is warranted, see section 6.

${ }^{7} \mathrm{See}$ http://www.popexpo.net/english.html, also for other population information.
} 
The uneven distribution of people across the global regions provides only a limited view of the distribution of economic activity. One person may be much more productive than another, for example as a result of better schooling, the availability of powerful machinery, good (rail-, water-, or regular) roads, efficient communication, a stable and secure system of law, etc. To measure economic activity we have to take three steps. First, a well-functioning statistics office will have to gather accurate information regarding the value of millions of different goods produced by all firms in an area. This occurs, of course, in local currency, that is euro in Western Europe, dollars in America, and yen in Japan. Second, we have to determine what to compare between different areas: the production of all goods or of specific types of goods, of goods produced in an area (domestic product), or of goods produced by factors of production owned by inhabitants of an area (national product), etc. Third, we have to decide how to compare the gathered information for the various areas.

In this section we concentrate on a comparison of gross national product (GNP) as it provides the best indication of all kinds of economic activity in an area. ${ }^{8}$ GNP is equal to the market value of all goods produced by factors of production owned by inhabitants of an area. This implies we are literally comparing apples and oranges, measured in a common domestic currency. For an international comparison, we can then for example use the average exchange rate on the currency markets in this period. Measured accordingly, the total world production of goods in 2000 was valued at $\$ 31,351$ billion, a truly astronomical figure. Obviously, this value is highest for the high income countries (HIC), with a total of $\$ 24,945$ billion, more than 82 times the production value of $\$ 303$ billion in Sub-Sahara Africa (SSA). Usually, our attention focuses on differences in income per capita, and it is clear that these differences are substantial. To determine the distribution of economic activity, however, the interaction between population density and productivity differences is important, so it is best to focus on production density per area unit (in this case GNP $\$ 1000$ per $\mathrm{km}^{2}$ ). This turns out to be highest for the high income countries (HIC; $\$ 807$ thousand per $\mathrm{km}^{2}$ ), being more than 62 times higher than for Sub-Sahara Africa (SSA; $\$ 13$ thousand per $\mathrm{km}^{2}$ ).

Based on the above information, it appears that the distribution of economic activity is more uneven than the distribution of population. Although true in general, we should note that the method of comparison (using the average exchange rate in a given period) leads to an overestimation of the value of production in high income countries relative to low income countries. The distinction between tradable and non-tradable goods is important in this respect.

\footnotetext{
${ }^{8}$ At this level of aggregation there is virtually no difference between GNP and GDP.
} 
Since tradable goods can in principle be shipped to other regions (perhaps at considerable costs), the suppliers of tradable goods more or less compete with each other on a global market based on the exchange rate, which is partly determined by these activities. Non-tradable goods, on the other hand, are produced and consumed locally and do not compete on a global market. Since (i) different sectors in an economy compete for the same worker, such that (ii) the wage rate in an economy reflects average productivity, and (iii) the productivity differences between countries are larger for tradable goods than for non-tradable goods, using the exchange rate as a basis for comparison for non-tradable goods leads to an underestimate of the value of production in low income countries. Using the exchange rate as a basis for comparison, it may cost for example $\$ 15$ to get a simple haircut in Chicago and less than $\$ 1$ to get the same haircut in Tanzania. Similarly, if you go to the latest James Bond movie in Rotterdam it will cost $\$ 8$, while viewing the same movie in the Philippines will cost $\$ 1.50$.

To correct for these price difference for non-tradable goods, the United Nations International Comparison Project (ICP) gathers information on the prices of goods in virtually all countries of the world. It uses the information to calculate purchasing power parity (ppp) corrected exchange rates. Table 1 also provides an overview of GNP ppp for the various global regions using the ppp exchange rates. This gives a better picture of the real economic activity in an area. The total value of world production is then $\$ 44,459$ billion, ranging from $\$ 24,793$ billion for the high income countries (HIC) to $\$ 1,044$ billion for Sub-Sahara Africa. Using this to calculate production density in $\$$ thousand per $\mathrm{km}^{2}$, the high income countries are still in the lead, with a value of $\$ 802$ thousand, more than 18 times higher than the $\$ 44$ thousand in Sub-Sahara Africa. The differences in production density therefore become considerably smaller after correcting for purchasing power, but do not disappear. The distribution of economic activity is still very uneven across the globe.

Conclusion: There are large differences in the distribution of economic activity between the global regions analyzed in this section. The relative density differences (highest density / lowest density) are large regarding population density (more than 14), GNP density (more than 62), and GNP density corrected for purchasing power differences (more than 18).

\section{Concentration at the country level}

After illustrating the uneven distribution of economic activity at the level of global regions in section 2, we focus on differences at the country level in this section. We start with all countries 
in the world, and zoom in on the countries of Sub-Sahara Africa, one of the global regions analyzed in section 2 , towards the end of this section.

Figure 1 Variation in population density; 195 countries (2000)

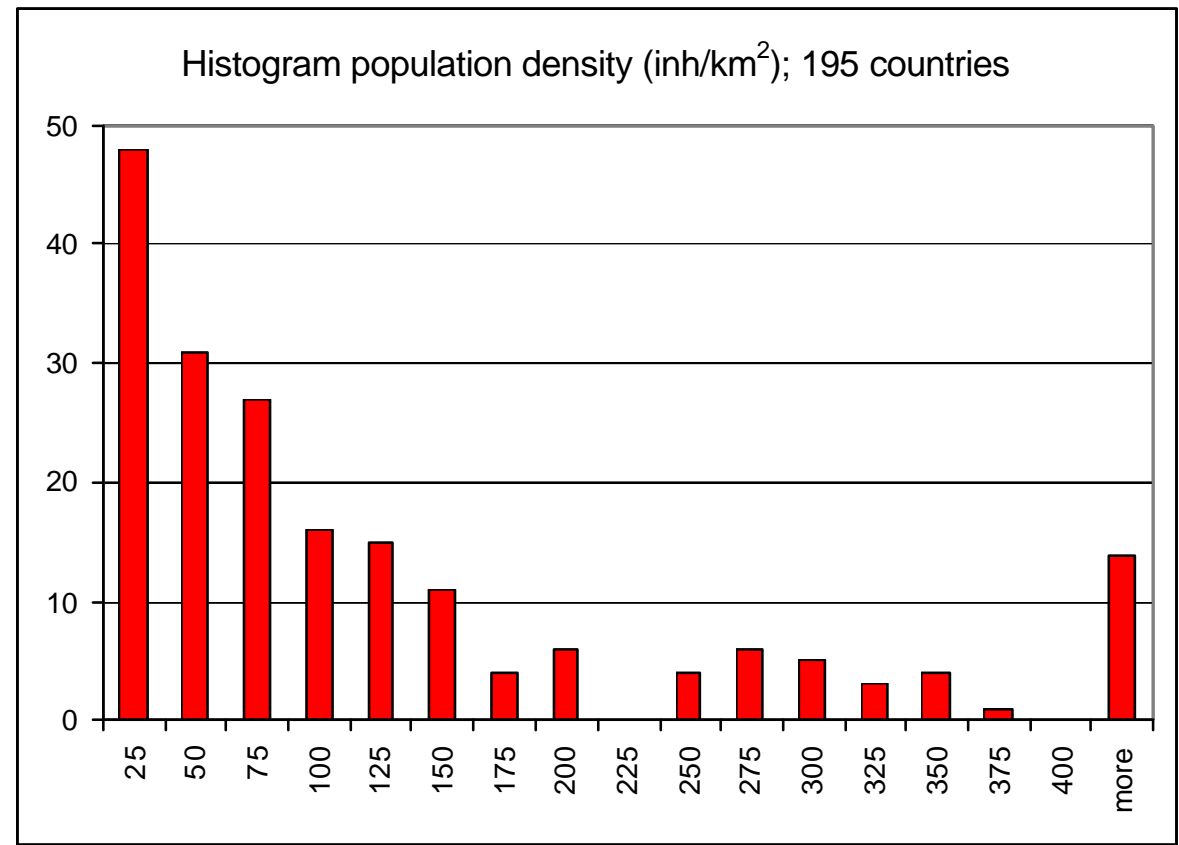

The World Bank provides information regarding the population density for 195 countries in the world. On average there are 47 persons per $\mathrm{km}^{2}$. At the country level this varies from 6,587 for Singapore (no less than 140 times the world average) to 0.16 for Greenland (part of Denmark), or to 1.53 for Mongolia. The differences between countries are therefore enormous, see also Figure 1. We should note, however, that the city-state of Singapore is an exception, as its population density is five times as high as the second-highest density (Bermuda's 1,260 people per $\mathrm{km}^{2}$ ). Table 2 gives an overview of the 15 countries with the highest population density. These are all small geographic areas, with the exception of Bangladesh (number 4), South Korea (number 10), and the Netherlands (number 11). It is therefore no surprise that only a minority of the number of countries (about 40 percent) has a population density below the world average. As illustrated in Figure 2, the countries with a high population density are geographically concentrated in South-East Asia and Europe, with a few exceptions in Africa and Mid America. 
Figure 2 Geographic distribution of population density; 195 countries (2000)

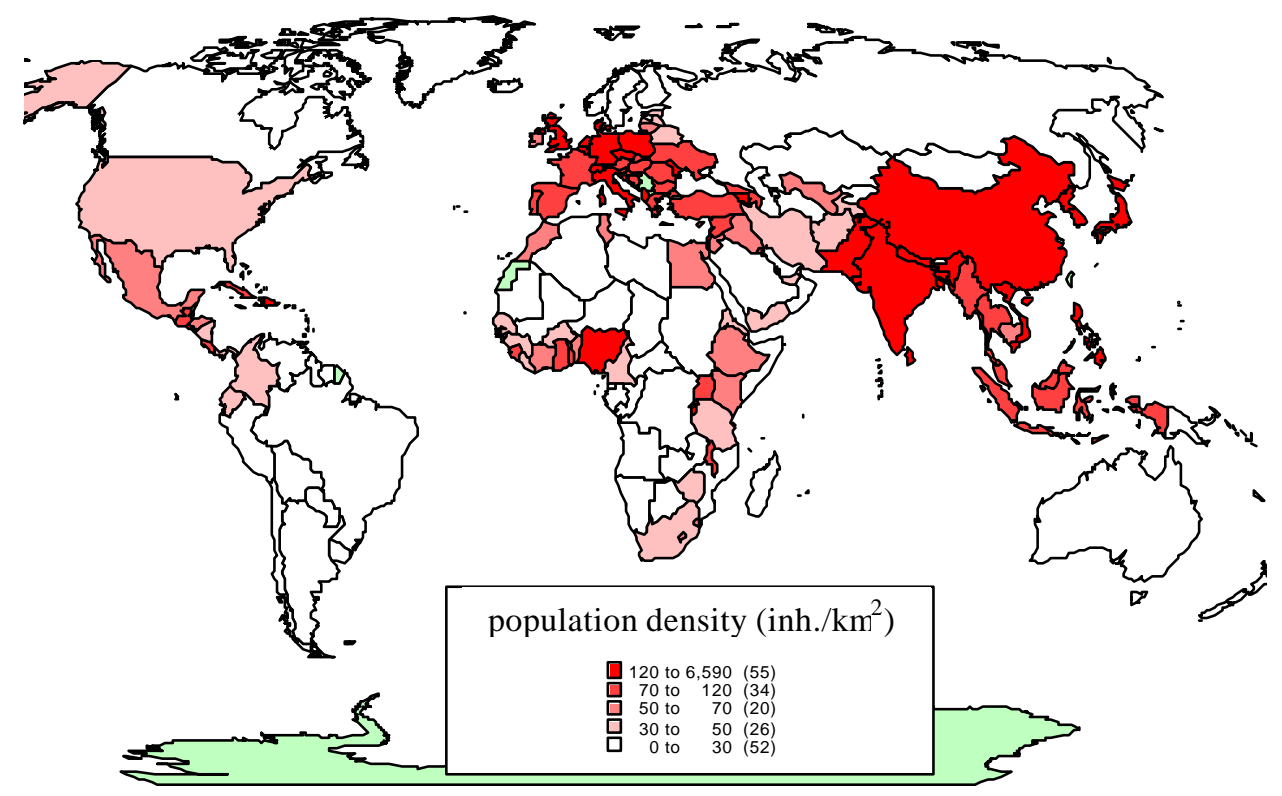

Table 2 Top 15 density of economic activity (2000)

\begin{tabular}{|c|c|c|c|c|}
\hline rank & country & pop dens & country & GNP ppp dens \\
\hline 1 & Singapore & 6.587 & Singapore & 164,05 \\
\hline 2 & Bermuda & 1.260 & Malta & 20,15 \\
\hline 3 & Malta & 1.219 & Netherlands & 12,15 \\
\hline 4 & Bangladesh & 1.007 & Japan & 9,43 \\
\hline 5 & Bahrain & 1.001 & Barbados & 9,33 \\
\hline 6 & Maldives & 920 & Belgium & 8,58 \\
\hline 7 & Barbados & 621 & South Korea & 8,28 \\
\hline 8 & Mauritius & 584 & Israel & 5,84 \\
\hline 9 & Aruba & 532 & United Kingdom & 5,84 \\
\hline 10 & South Korea & 479 & Mauritius & 5,81 \\
\hline 11 & Netherlands & 470 & Germany & 5,74 \\
\hline 12 & San Marino & 450 & Switzerland & 5,53 \\
\hline 13 & Puerto Rico & 442 & Italy & 4,60 \\
\hline 14 & Lebanon & 423 & Maldives & 3,90 \\
\hline 15 & Virgin islands & 356 & Denmark & 3,43 \\
\hline
\end{tabular}

pop dens $=$ population density $\left(\right.$ people per $\left.\mathrm{km}^{2}\right)$; GNP ppp dens in $\$$ million per $\mathrm{km}^{2}$. 
As explained in section 2, to get an adequate picture of the distribution of economic activity it is better to correct for differences in productivity and purchasing power between countries. The World Bank provides the relevant data for 160 countries in the world, with an average ppp corrected value of production of $\$ 342$ thousand per $\mathrm{km}^{2}$ in 2000 . Table 2 also lists the 15 countries with the highest production density. Singapore is again in the lead, with a value of $\$ 164,05$ million per $\mathrm{km}^{2}$, which is 480 times the world average, 8 times as high as number two (Malta; \$20.15 million), and almost 14 times as high as number three (the Netherlands; \$12.5 million). The top 15 in production density also lists large countries, like Japan (number 4), South Korea (number 7), the United Kingdom (number 9), Germany (number 11), and Italy (number 13). Consequently, about 57 percent of all countries has a production density below the world average. Seven countries are both in the top 15 in terms of population density and in terms of production density. As suggested by this fact and by Singapore's solid first place on both lists, there is a positive association between population density and production density at the country level: the correlation coefficient is 0.73 . There is also a geographic clustering of production density around the core of rich countries: Europe, Japan, and the United Stated, see Figure 3. Of the less developed countries the high production density of Bangladesh (number 26), the Philippines (number 39), and Sri Lanka (number 41) are remarkable. These are, indeed, all countries with a high population density, ranked $4^{\text {th }}, 32^{\text {nd }}$, and $23^{\text {rd }}$, respectively.

Figure 3 Geographic distribution of production density; 160 countries (2000)

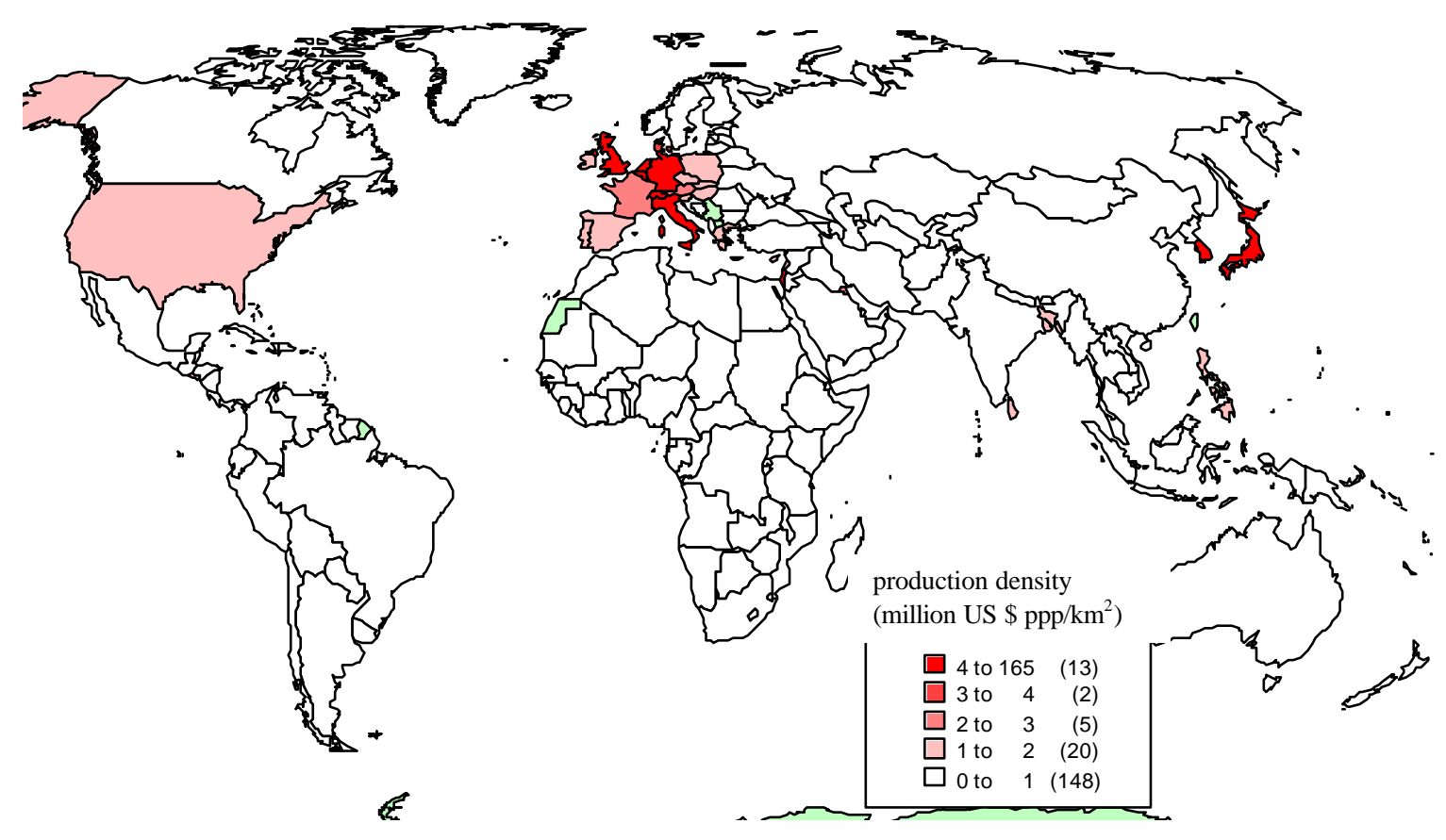


If we break down the global regions of section 2 into the countries composing those regions, as we did above, it is not remarkable that the uneven-ness of the distribution increases. As we saw, however, the extent of this increase is remarkable. We can also disaggregate geographically in a different way. After noting that economic activity is unevenly distributed at the level of global regions, we can 'zoom in' on one of those regions and analyze the distribution of economic activity within that region. As an example, we take Sub-Sahara Africa, a relatively coherent geographical region consisting of a fairly large (48) number of individual countries. Table 3 gives an overview of the countries in Sub-Sahara Africa with the highest and lowest population and production densities, and the averages of these variables for the region as a whole.

Table 3 Variation in density within Sub-Sahara Africa (SSA; 2000)

\begin{tabular}{|c|c|c|c|}
\hline \multicolumn{4}{|c|}{ Average density } \\
\hline area & pop dens & area & GNP ppp dens \\
\hline$\overline{\text { SSA }}$ & 28 & SSA & 44 \\
\hline \multicolumn{4}{|c|}{ Highest density } \\
\hline country & pop dens & country & GNP ppp dens \\
\hline Mauritius & 584 & Mauritius & 5.809 \\
\hline Rwanda & 345 & Cape Verde & 525 \\
\hline Burundi & 265 & Comoros & 444 \\
\hline Comoros & 250 & South Africa & 321 \\
\hline Seychelles & 181 & Rwanda & 317 \\
\hline \multicolumn{4}{|c|}{ Lowest density } \\
\hline country & pop dens & country & GNP ppp dens \\
\hline Central African Rep. & 6,0 & Central African Rep. & 6,9 \\
\hline Gabon & 4,8 & Niger & 6,3 \\
\hline Botswana & 2,8 & Chad & 5,3 \\
\hline Mauritania & 2,6 & Congo, Rep. & 5,1 \\
\hline Namibia & 2,1 & Mauritania & 4,2 \\
\hline
\end{tabular}

The average population density in Sub-Sahara Africa is 28 people per $\mathrm{km}^{2}$, varying from 584 for Mauritius (more than 20 times the average) to 2.1 for Namibia (less than 10 percent of the average). The production density varies in a similar fashion: the average is $\$ 44$ thousand per $\mathrm{km}^{2}$ in 2000 , ranging from $\$ 5,809$ thousand in Mauritius (more than 130 times the average) to 
$\$ 4.2$ thousand in Mauritania (less than 10 percent of the average). For both density measures the variation within the Sub-Sahara Africa global region is enormous. Again, there is a clear positive association between population density and production density: for the 42 countries for which data are available the correlation coefficient is 0.79 .

Conclusion: At a lower level of geographic aggregation, in this case at the country level, the uneven distribution of economic activity becomes more pronounced, both for population and production (measured as value added, after correcting for purchasing power).

\section{Deeper still: regional periphery and urban concentration}

In this section we will first apply the procedure used at the end of section 3 (where we looked at the countries comprising Sub-Sahara Africa) again at the country level (in this case by looking at the different regions of the Netherlands). Second, we will illustrate the core - periphery economic structure of Europe at the regional level using a periphery index. Third, we will illustrate the dynamic tendency of increasing economic concentration at the city level for the world as a whole.

The regional classification used within the European Union is based on three levels of detail, known as the Nomenclature of Territorial Units for Statistics (NUTS) and therefore referred to as NUTS I, NUTS II, and NUTS III. At the NUTS I level the Netherlands is subdivided into 4 regions (North, East, West, and South). At the NUTS II level, these are subdivided in 12 subregions (the 12 Dutch provinces). At the NUTS III le vel, finally, these are subdivided again into 40 sub-sub-regions, see Table 4 (see below for the periphery indices in this table). In 1997 the average population density in the Netherlands was 380 people per $\mathrm{km}^{2}$. At the NUTS III (subsub-region) level this varied from 86 for South-West Friesland (23 percent of the average) to 2,815 for the agglomeration of The Hague (740 percent of the average). In 1996 the average production density in the Netherlands was 7,620 euro per $\mathrm{km}^{2}$, varying from 1,261 for SouthWest Friesland (17 percent of the average) to 63,899 for the agglomeration of The Hague (839 percent of the average). As suggested by the stable first and last place of the same region on both lists, the positive association between population density and production density is high: the correlation coefficient is equal to 0.981 . 
Table 4 Economic activity in the Netherlands and periphery indices

\begin{tabular}{|c|c|c|c|c|c|c|c|}
\hline & & \multicolumn{2}{|c|}{ density } & \multicolumn{4}{|c|}{ periphery index } \\
\hline & & pop. & prod. & GDP & GDP ppp & pop & labor force \\
\hline \multicolumn{2}{|c|}{ Netherlands } & 380 & 7,620 & & & & \\
\hline NL1 & North-Netherlands & 144 & 2,786 & & & & \\
\hline NL11 & Groningen & 188 & 4,725 & & & & \\
\hline NL111 & East Groningen & 168 & 2,083 & 50.4 & 50.9 & 58.8 & 59.8 \\
\hline NL112 & Delfzijl and surr. & 147 & 2,497 & 52.7 & 53.2 & 62.2 & 63.2 \\
\hline NL113 & Misc. Groningen & 208 & 6,619 & 49.9 & 50.2 & 58.4 & 59.5 \\
\hline NL12 & Friesland & 107 & 1,758 & & & & \\
\hline NL121 & North Friesland & 94 & 1,638 & 51.9 & 52.2 & 60.8 & 62.1 \\
\hline NL122 & South-West Friesland & 86 & 1,261 & 50.5 & 50.7 & 58.6 & 60.0 \\
\hline NL123 & South-East Friesland & 168 & 2,599 & 49.7 & 50.0 & 57.7 & 59.0 \\
\hline NL13 & Drenthe & 173 & 2,832 & & & & \\
\hline NL131 & North Drenthe & 183 & 2,888 & 49.4 & 49.7 & 57.3 & 58.5 \\
\hline NL132 & South-East Drenthe & 191 & 3,388 & 48.9 & 49.3 & 56.4 & 57.7 \\
\hline NL133 & South-West Drenthe & 148 & 2,318 & 46.2 & 46.5 & 51.9 & 53.5 \\
\hline NL2 & East-Netherlands & 309 & 5,377 & & & & \\
\hline NL21 & Overijssel & 310 & 5,444 & & & & \\
\hline NL211 & North Overijssel & 214 & 3,857 & 44.2 & 44.5 & 48.5 & 50.2 \\
\hline NL212 & South-West Overijssel & 330 & 6,300 & 40.8 & 41.1 & 42.2 & 44.1 \\
\hline NL213 & Twente & 411 & 6,952 & 42.5 & 43.1 & 46.0 & 47.9 \\
\hline NL22 & Gelderland & 368 & 6,560 & & & & \\
\hline NL221 & Veluwe & 333 & 5,999 & 39.7 & 40.0 & 40.6 & 42.6 \\
\hline NL222 & Achterhoek & 244 & 4,093 & 40.9 & 41.3 & 42.7 & 44.7 \\
\hline NL223 & Arnhem/Nijmegen & 685 & 12,760 & 38.0 & 38.2 & 37.5 & 39.6 \\
\hline NL224 & South-West Gelderland & 287 & 4,812 & 38.9 & 39.0 & 39.4 & 41.6 \\
\hline NL23 & Flevoland & 149 & 2,090 & 45.7 & 45.8 & 51.9 & 53.4 \\
\hline NL3 & West-Netherlands & 615 & 13,257 & & & & \\
\hline NL31 & Utrecht & 756 & 17,013 & 36.7 & 36.6 & 35.7 & 37.6 \\
\hline NL32 & North-Holland & 614 & 13,883 & & & & \\
\hline NL321 & Top of North-Holland & 163 & 2,395 & 52.4 & 52.6 & 61.9 & 63.3 \\
\hline NL322 & Alkmaar and surr. & 697 & 11,115 & 44.8 & 44.9 & 50.3 & 51.8 \\
\hline NL323 & IJmond & 983 & 19,482 & 48.8 & 48.9 & 56.9 & 58.5 \\
\hline
\end{tabular}


Table 4 continued

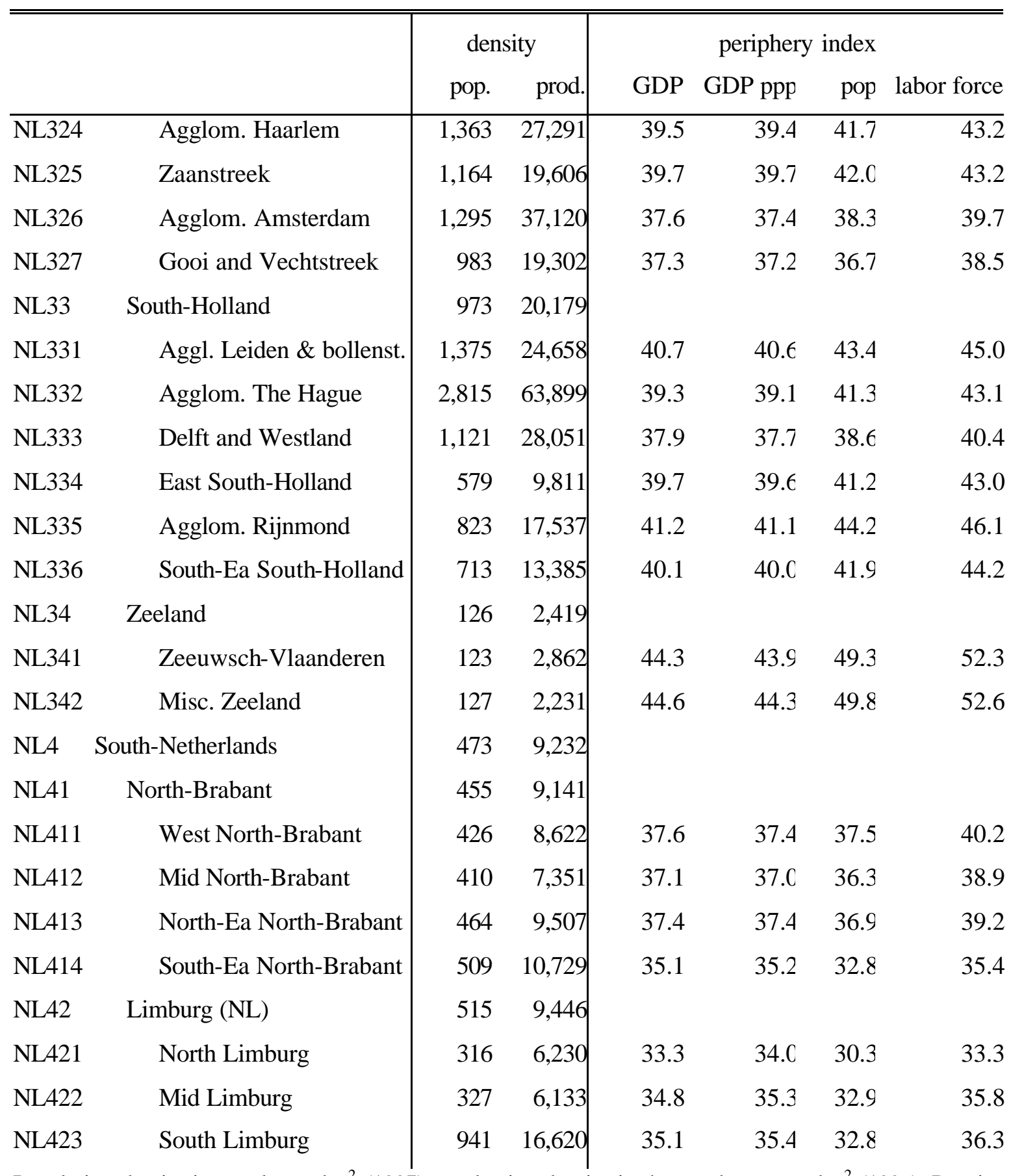

Population density in people per $\mathrm{km}^{2}$ (1997); production density in thousand euro per $\mathrm{km}^{2}$ (1996). Density calculations based on Eurostat data; periphery indices: Copus (1999).

The above descriptive analysis has sufficiently demonstrated that economic activity, measured in various ways at different levels of aggregation, is unevenly distributed across space and that the various measures of density and production are strongly correlated. Regional economists have long ago already felt a need to measure this uneven-ness, and subsequently to identify and analyze core - periphery structures. Harris's (1954) 'market potential' approach is at the basis 
of this procedure, namely by calculating an indicator of market potential at the county level, taking into consideration the size of economic markets in the vicinity of this county, corrected for distance to this market. The demand by policy makers to identify core - periphery structures and analyze the economic consequences of such structures led Keeble, Owens, and Thompson (1981) to apply Harris's approach to construct a peripherality index for the regions of the European Union at the NUTS I level. Over the years, the methods used for calculating such a peripherality index have become more sophisticated, ultimately leading to Andrew Copus's (1999) study of 1,105 European regions (at the NUTS III level for the European Union plus 19 European countries). For each region Copus defines a 'center' (usually the largest city, but sometimes the geometric center) and calculates detailed travel times to other centers, taking into consideration the type of road, ferries, waiting times for ferries and crossing a border, driving speeds in mountains and urban areas, rest times for drivers, etc. ${ }^{9}$ Copus uses this as the basis for calculating the potential for each region as follows:

$$
\begin{aligned}
& P_{i}=\sum_{j} M_{j} / D_{i j} \quad \text {, in which } \\
& P_{i} \quad \text { potential for region } i \\
& M_{j} \quad \text { economic mass of region } j \\
& D_{i j} \quad \text { distance between regions } i \text { and } j
\end{aligned}
$$

An adequate economic theoretical explanation for the structure of equation (1) is not simple. It is the basis for a substantial body of economic research, culminating in the "new economic geography' or 'geographical economics' approach (Fujita, Krugman, and Venables, 1999, and Brakman, Garretsen, and Van Marrewijk, 2001). For the distances between regions Copus uses the travel times, as described above. For the economic mass of a region he uses four indicators:

- GDP Gross Domestic Product in euro's

- GDP pps

- pop Gross Domestic Product, corrected for purchasing power

- labor force Population size

Finally, on the basis of this outcome, he calculates a periphery index ranging from 0 for the most central region (with the highest potential) to 100 for the peripheral region (with the lowest potential). Which measure is used exactly as an indicator of 'economic mass' for constructing the peripherality index hardly matters, see Table 5 .

\footnotetext{
${ }^{9}$ The distance of a region to itself equals $1 / 3$ of the axis of the smallest rectangle containing the region.
} 
Table 5 Correlation coefficients for Copus periphery indices

\begin{tabular}{l|cccc}
\hline \hline & GDP & GDP ppp & pop & labor force \\
\hline GDP & 1 & 0.996 & 0.978 & 0.977 \\
GDP ppp & 0.996 & 1 & 0.980 & 0.975 \\
pop & 0.978 & 0.980 & 1 & 0.995 \\
labor force & 0.977 & 0.975 & 0.995 & 1
\end{tabular}

Table 4 also gives the results of the Copus (1999) periphery index calculations for the 40 NUTS III regions in the Netherlands. Again, the used indicator of economic mass is hardly relevant (the lowest correlation coefficient is 0.996 , see Table 5). In all cases, the most central region is North Limburg. In three out of four cases Delfzijl and surroundings is the most peripheral region (only on the basis of population the Top of North Holland is classified as such). We note, of course, that the region with the highest economic density (The Hague) is not the most central region in the Netherlands (depending on the index used, it is ranked $14^{\text {th }}$ or $16^{\text {th }}$ ). The most important reason is that the Copus periphery indices identify core - periphery structures at the European level, and thus take into consideration the location of other European regions. In view of their location close to the Dutch Randstad (Amsterdam, Rotterdam, the Hague, and Utrecht) and the German Ruhrgebiet and Brussels in Belgium, the three Limburg regions together with South-East North Brabant are always the four most central regions in the Netherlands. The first Randstad region is Utrecht ( $5^{\text {th }}$ place). The regions in Groningen, Friesland, Drente, and the Top of North Holland constitute the Dutch periphery.

At the European level, none of the Dutch regions is located in the periphery, as even the most peripheral Dutch region is in the top half of the rankings. To illustrate this at a not too detailed level of analysis while using the detailed Copus data, Figure 4 depicts the European core periphery structures at the NUTS I level using the average score of the NUTS III components (GDP, corrected for purchasing power). At the European level, the southern half of the Netherlands is part of a big European core, consisting also of Flanders, Brussels, NordrheinWestfalen, Hessen, Rheinland-Palts, and London. Almost all of the Netherlands, Belgium, and West Germany is economically centrally located. Paris is a fairly separate economic entity, although still linked to the European core. Other examples are Lombardy (Milan), Berlin, and Madrid. Clearly, some of the new European Union members entering on May 1 2004, such as Poland, the Czech Republic, and Slovakia, are economically more centrally located than some of the older EU members, such as Greece, Finland, Sweden, Portugal, Ireland, Scotland, and parts of Italy. 
Figure 4 Core - periphery structures in Europe (based on GDP pps)

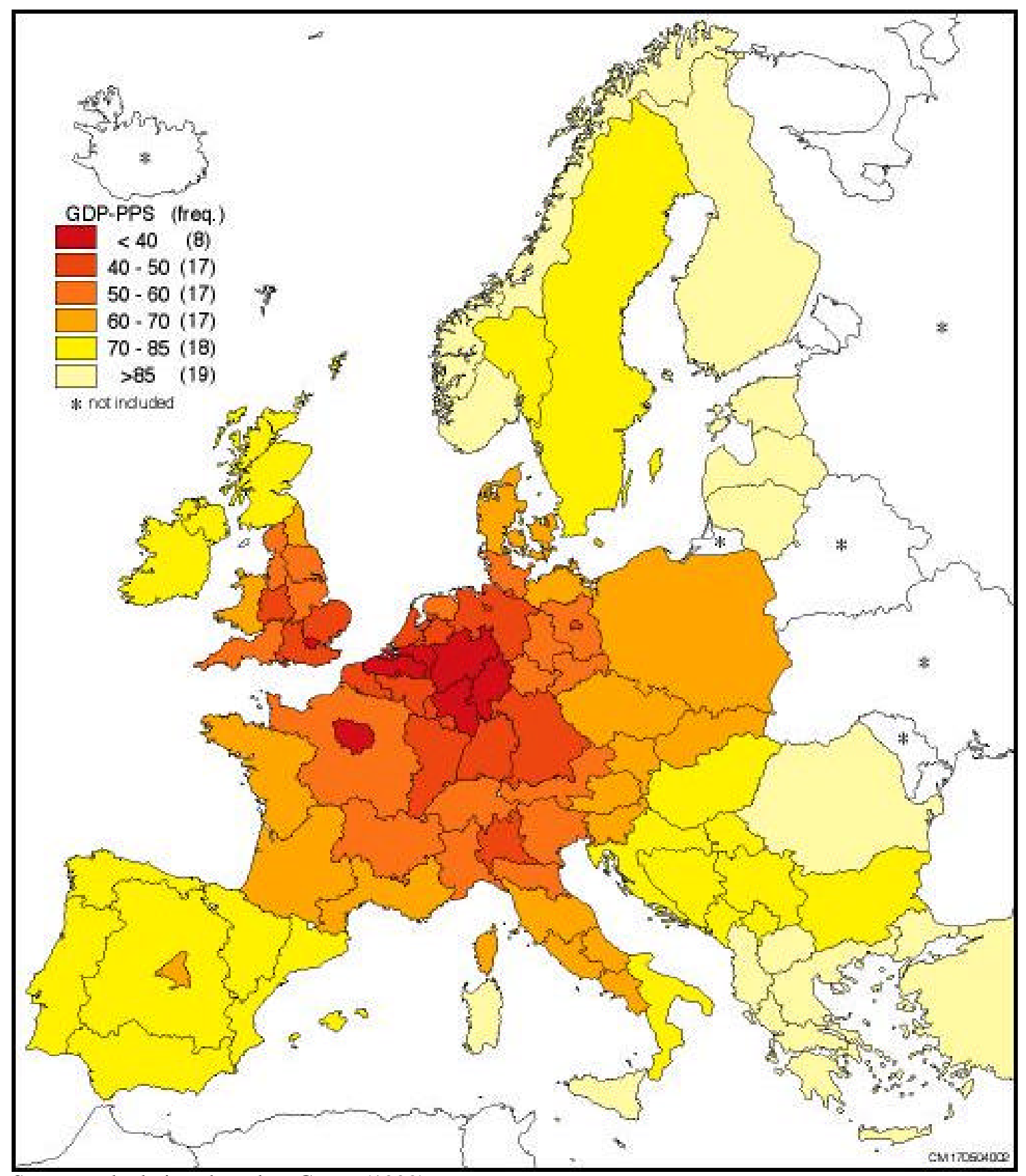

Source: calculations based on Copus (1999).

If we look in more detail at the spatial distribution of economic activity within a region of a country, we have to investigate the distribution of cities and villages. A process of urbanization has been noticeable worldwide for a considerable time. Of the 3,021 million people living on our planet in 1960, about 1,017 million (almost 34 percent) lived in the city. ${ }^{10}$ In the next 40 years, the number of people on our planet doubled to 6,057 million in 2000 . The number of 
people in urban areas rose relatively more rapidly, to 2,848 million (47 percent of the population). Obviously, this does not mean that the population in the rural areas falls (it rose from 2,004 million in 1960 to 3,210 million in 2000), just that the urban population rises more rapidly. At this rate, the urban population will be larger than the rural population by the year 2009. The process of urbanization has been virtually completed in many countries. In the Netherlands, for example, the urban population rose from 85.0 percent in 1960 to 89.4 percent in 2000. Of the global regions identified in section 2, urbanization in the period 1960-2000 has been highest in Latin America in percentage points (LAC; from 49.3 percent to 75.4 percent) and in Sub-Sahara Africa in relative terms (SSA; from 14.5 percent to 34.4 percent). As the urbanization process is largely completed in most high income countries, the increase has been lowest in percentage and relative terms in those countries (HIC; from 67.8 percent to 78.9 percent), see Figure 5.

Figure 5 Urbanization; globalregions and world (1960-2000)

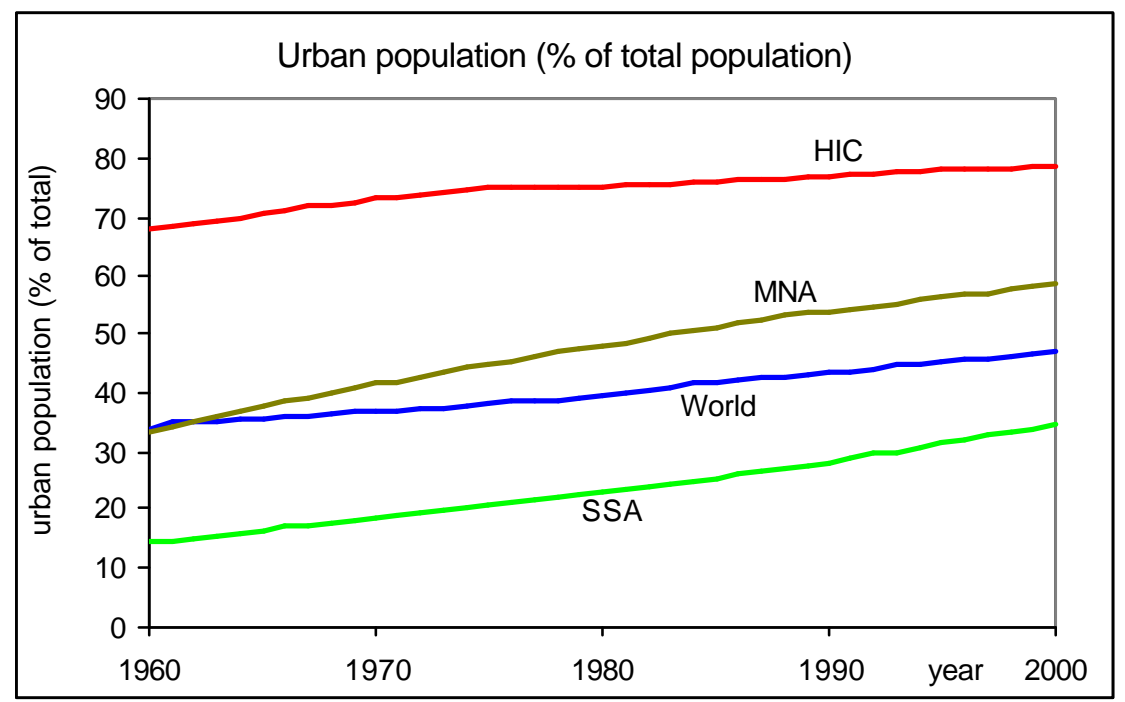

According to the World Bank (2000), the majority of the urban population (63.5 percent) lives in small- and medium-sized cities (population smaller than 1 million), whereas 21.4 percent lives in large cities (population between 1 and 5 million), and 'only' 15.1 percent lives in megacities (population above 5 million). The number of mega-cities has, however, rapidly increased in the $20^{\text {th }}$ century; London (6.5 million inhabitants) was the only mega-city in 1900 , whereas there were 16 cities with more than 10 million inhabitants in 2000.

Conclusion: A 'fractal dimension' in the distribution of economic activity becomes clear now that we have established that at the regional and city level economic activity is also unevenly

\footnotetext{
10 This is the population identified as living in an urban area. Note that this definition may vary from country to country, which leads to an underestimate of the urban population in e.g. China and India.
} 
distributed. This enables the identification of core - periphery patterns at the regional level. The degree of urbanization, which varies from country to country, is still increasing worldwide.

\section{The fractal dimension of regularity in concentration}

Now that we have sufficiently illustrated the uneven distribution of economic activity, it is time to analyze the empirical structure of that distribution. We will do this in two ways. In this section we focus on the spatial distribution of economic activity, known as the 'rank-size rule' (with 'Zipf's Law' as a special case). In the next section we focus on the spatial interaction between economic centers, known as the 'gravity equation'. Both empirical regularities have inspired theorists in geography and economics to try to construct models to improve our understanding of these facts. As noted before, we do not discuss these theoretical contributions.

Figure 6 Regularity in the distribution of economic activity: urban agglomerations in the world

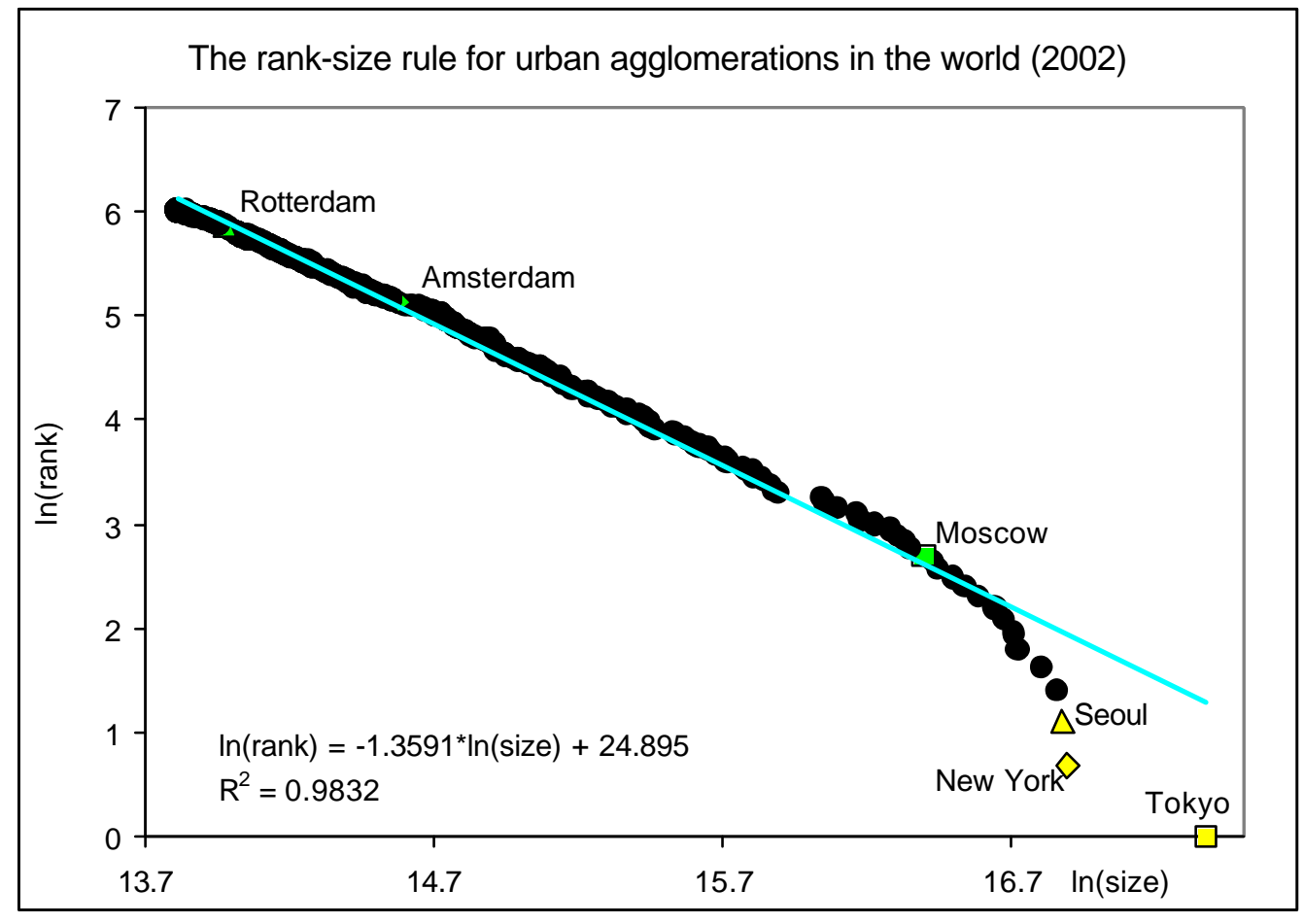

The regularity in the spatial distribution of economic activity is most easily demonstrated using the size distribution of urban agglomerations. There are cities in many sizes. Most are small or of reasonable size. A few are truly large, with millions of inhabitants. We should note that 'large' has been a relative measure in history. When Christ was born, Rome was considered to be an extremely large city with, according to the New Zealand classicist Art Pomeroy, at least 500,000 inhabitants (some estimates are up to 1 million). Nowadays, however, there are more than 400 cities with more than 1 million inhabitants (see below). 
A well-known problem in comparing or measuring the size of cities, is the distinction between urban agglomeration and city proper (official boundaries). The latter usually arose in a complex historical process of evolution, annexation, and coincidence. A ranking based on city proper sizes therefore usually gives a less complete picture of economically relevant size. The city of Rotterdam, for example, had 599,463 inhabitants on 1 November 2002 according to the Dutch Central Bureau of Statistics. Other municipalities in the direct vicinity, such as Schiedam (75,901 inhabitants) and Capelle aan den IJssel (65,304 inhabitants), are effectively part of the same economic entity with the city of Rotterdam. Together with some other municipalities, they constitute the agglomeration of Rotterdam. The data we use here is taken from Thomas Brinkhoff's website ${ }^{11}$, which tries to compare the size of city agglomerations worldwide as much as possible on calculating the central city (or sometimes the central cities, such as for the Ruhrgebiet) together with economically associated surrounding municipalities.

There were 408 agglomerations in the world with more than 1 million inhabitants in 2002, of which Tokyo (including Yokohama and Kawasaki) was the largest with 35.1 million inhabitants, followed by New York (21.65 million), and Seoul (21.35 million). The largest European agglomeration is Moscow (13.2 million, $15^{\text {th }}$ place). The above mentioned agglomeration of Rotterdam is ranked $350^{\text {th }}$ (1.175 million), preceded in the Netherlands by the agglomeration of Amsterdam (2.1 million, $170^{\text {th }}$ place). To illustrate the regularity in the spatial distribution of economic activity, we rank the cities in size. The largest city (Tokyo) is given rank 1, the second largest city (New York) is given rank 2, etc. We then calculate the natural logarithm of the rank of each city and the natural logarithm of the size of each city. Figure 6 plots the 408 data points calculated accordingly in a graph. With the exception of the largest cities (a well-known phenomenon in the literature, see Brakman, Garretsen, and Van Marrewijk, 2001, chapter 7), all data points are almost exactly on a straight line. A simple regression explains 98.32 percent of the variance in the data, see Figure 6. Based on its size, the rank number predicted by the regression for the city of Amsterdam (166), for example, is very close to the actual rank number (170). Similarly for the city of Rotterdam (actual 350, predicted 365). The negative relationship between rank and size follows, obviously, from our way of organizing the data. The almost perfect log-linear relationship between rank and size, indicating regularity and predictability in the spreading of economic activity, is highly remarkable. It was first discovered by George Kingsley Zipf (1949). In general, this is referred to as the rank-size rule. If the slope of the estimated regression is equal to one, it is referred to as 'Zipf's Law'.

\footnotetext{
${ }^{11}$ All data in this section are taken from that website (dated 12 November 2002), see Th. Brinkhoff: Principal Agglomerations and Cities of the World, http://www.citypopulation.de.
} 
Figure 7 Regularity in the distribution of economic activity: urban agglomerations in Europe

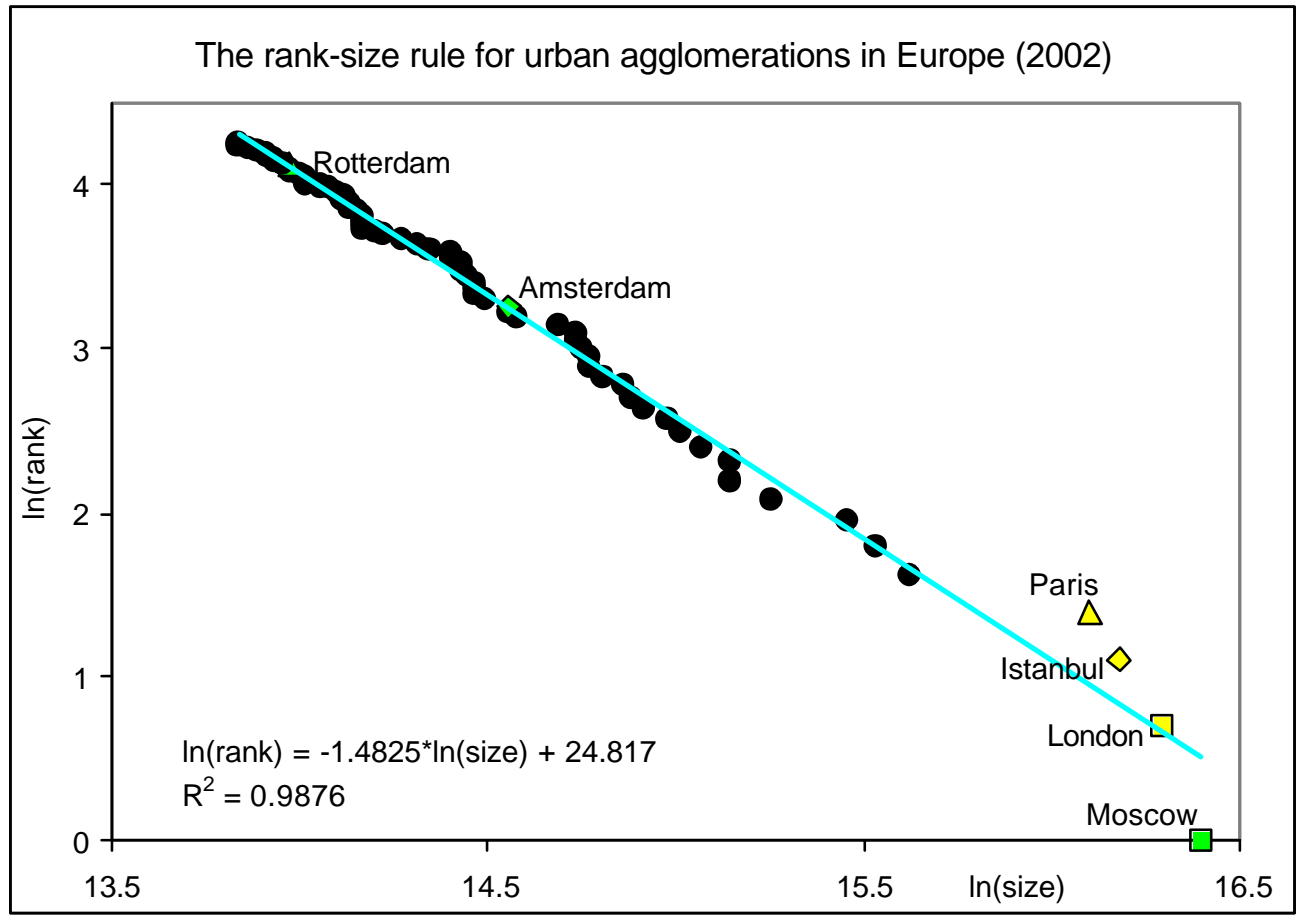

We will illustrate the fractal dimension in the regularity of the distribution of economic activity in a similar way as we did for the uneven-ness of this distribution. First, by showing that the same regularity holds if we limit ourselves to a global region, in this case Europe. Second, by repeating this exercise for one of the countries in Europe, in this case Germany. Moscow (13.2 million inhabitants) is the largest agglomeration in Europe, followed by London (11.85 million), Istanbul (10.65 million), and Paris (9.8 million). Within Europe, Amsterdam is placed $25^{\text {th }}$ and Rotterdam $61^{\text {st }}$. Similar calculations as performed before at the global level, again lead to the rank-size rule, see Figure 7 (note that the 'problem' with the largest cities is less pronounced than in Figure 6). A simple regression explains 98.76 percent of the variance in the data, which are again on an almost perfect log-linear line. The economic powers at work at the global level to create order in the distribution chaos, are apparently also operative at the European level.

Within Germany, Essen (5.93 million inhabitants) was the largest agglomeration in 1996, followed by Berlin (4.06 million), Stuttgart (2.52 million), Hamburg (2.46 million), and Frankfurt (1.87 million). Similar rankings and calculations as before lead to Figure 8, which again shows that the relationship between rank and size creates an almost perfect log-linear line. A simple regression explains 97.62 percent of the variance in the data. At the country level too, therefore, similar regulatory powers in the distribution of economic activity play a role. Brakman, Garretsen, and Van Marrewijk (2001, chapter 7) and Soo (2002) provide a detailed 
overview of the rank-size rule for all countries in the world for which data are available. In general, this rule holds no matter the size of a country, its political system, its cultural, social, or ethnical background, etc. Indeed, the rank-size rule on the empirical distribution of economic activity holds almost perfectly for such diverse countries as, for example, the United States, Brazil, France, India, Russia, and China.

Figure 8 Regularity in the distribution of economic activity: urban agglomerations in Germany

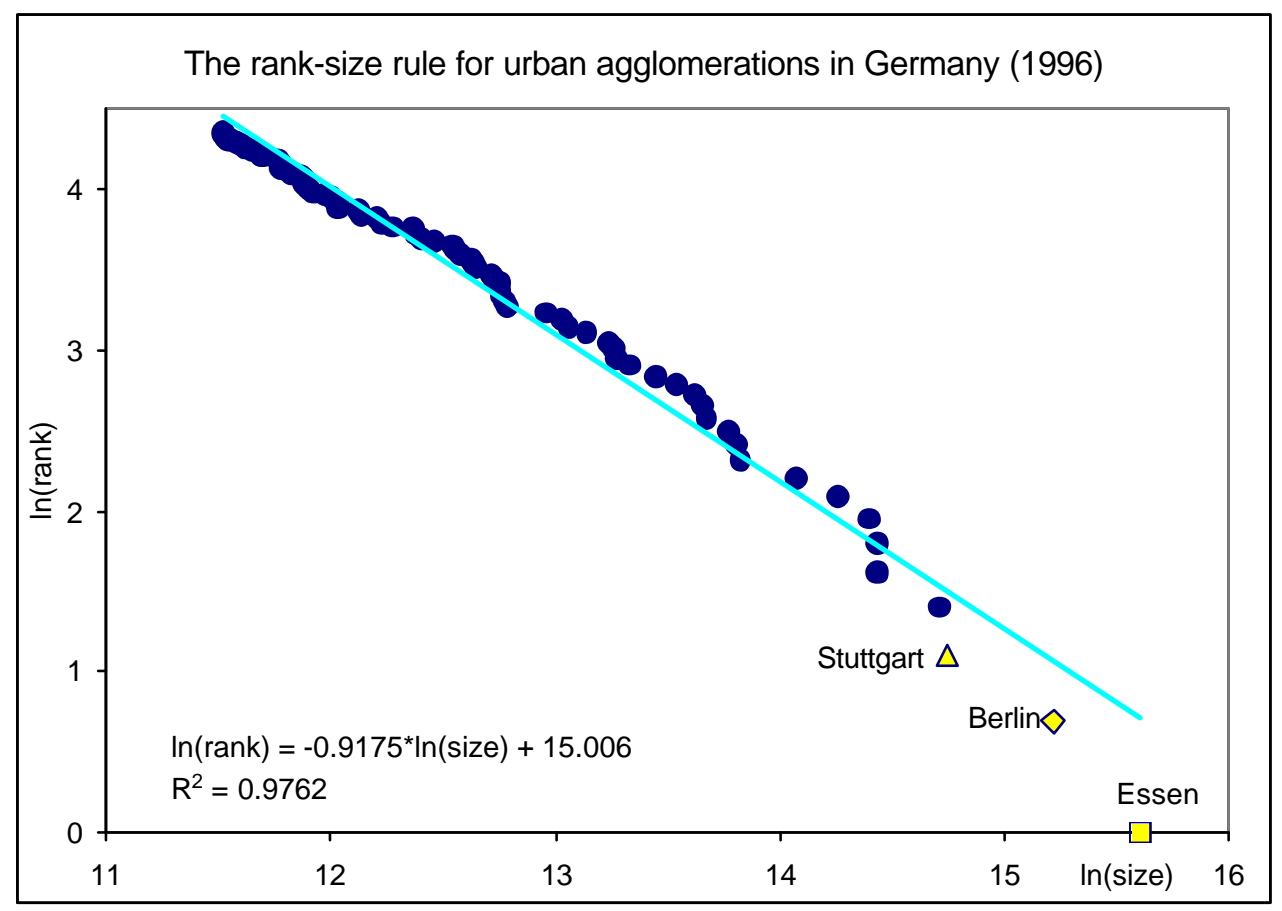

Conclusion: There is a 'fractal dimension' in the regularity of the spatial distribution of economic activity, known as the rank-size rule (with Zipf's Law as a special case). This empirical regularity holds globally, at the continent level, and at the country level.

\section{Regularity in interaction}

As explained in section 5, the spatial distribution of economic activity displays a remarkable regularity. In this section we will show that this also holds for the interaction between economic centers in the form of international trade flows. Before investigating the interaction at the country level, we first give an overview of this interaction at the global region level (see also section 2). In this respect it is useful to sub-divide the group of high income countries (HIC) into three sub-groups: Western Europe, North America, and AustralAsia. In combination with the six developing regions, this creates nine global regions. Our overview is based on a combination of the CID-UC-Davis/Feenstra (2000) data set, consisting of annual observations on bilateral trade flows for 4 digit sectors, 183 countries, and 28 years, with a total of slightly 
less than 18.4 million positive observations. ${ }^{12}$ First, we aggregated all data to the country level. Second, we calculated the intra-regional trade flows (that is, trade flows between countries in the same global region) and the inter-regional trade flows (that is, trade flows between countries in two different global regions).

Figure 9 Inter- and intra-regional trade flows; global regions (\% of world total, 1996)

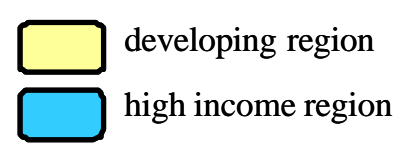

The thickness of an arrow is indicative of the size of the trade flow (percent of world trade flows, rounded to nearest integer)

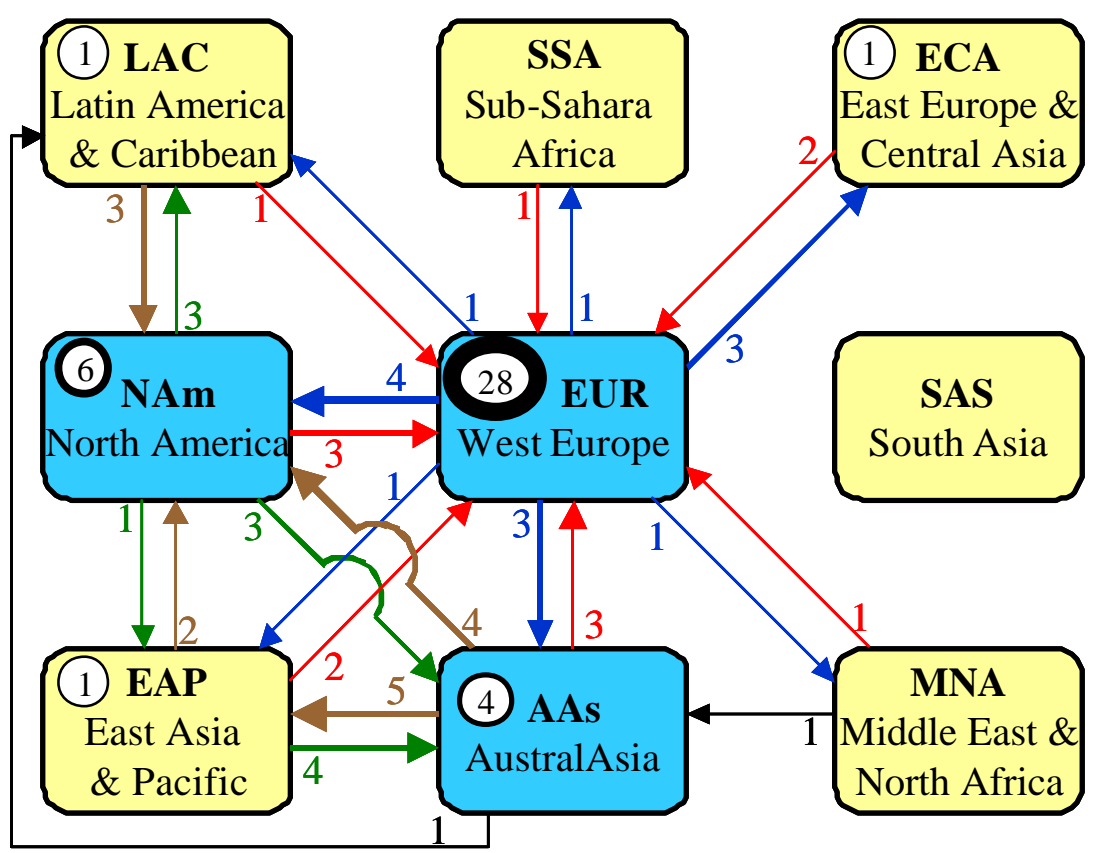

- 51 of the 81 inter- and intra-regional trade flows are smaller than 0.5 per cent; these are not shown in the picture.

- intra-regional trade flows are indicated by a circle in that region.

With a combined total of more than 75 percent of world trade, the three high income regions are the three largest trade regions. This image is reinforce once we take into consideration that these three regions only contain about 16 percent of the world population. Western Europe is by far the most important trade region within this group. It is the source of about 42 percent of world exports, more than twice as much as the other two high income regions (North America and AustralAsia), which each are the source of about 17 percent of world exports. South-East Asia is the most important developing region (10 percent of world exports), followed by Latin America (5 percent of world exports). The trade shares of South Asia and Sub-Sahara Africa (both about 1 percent of world exports) are remarkably small.

\footnotetext{
${ }^{12}$ See the eta - center website for details: www.few.eur.nl/few/people/vanmarrewijk/eta . We focus on
} 
Of the nine global regions identified here no less than 41.1 percent of world trade flows are intra-regional. There is, however, a large difference between the regions concerning the extent of intra-regional trade flows. South Asia (SAS; 2 percent), the Middle East and North Africa (NMA; 3 percent), and Sub-Sahara Africa (SSA; 4 percent) have very low intra-regional trade flows, implying that they depend mostly on (far away) other parts of the world for their export flows. North America (NAm; 35 percent) and (Eastern) Europe and Central Asia (ECA; 31 percent) have much higher levels of intra-regional trade flows. By far the highest level of intraregional trade flows is reached, however, in Western Europe (two-thirds of its trade flows), making it the only region with above-average intra-regional trade flows at the world level.

The most important information on international trade flows at the global region level is effectively illustrated in Figure 9. Since there are nine global regions, there are in principle $9 \times 8$ $=72$ inter-regional and 9 intra-regional trade flows. Expressed as a percentage of total world trade flows and rounded to the nearest integer, however, only 30 out of these possible 81 trade flows have a value of 1 or higher. These are shown in Figure 9. It is immediately evident that South Asia hardly participates in the global economy: none of its trade flows is large enough to be depicted in Figure 9. The central role of Western Europe (partially based on its past as a colonial power) is also evident. Finally, the local character of international trade flows becomes evident: the intra-regional trade flows are relatively large and the largest inter-regional trade flows are usually directed towards local global regions. This local character of international trade flows is at the center of the regularity in interaction between economic centers, known as the 'gravity equation'. Newton's second law states that the attraction between two objects is proportional to their mass and inversely related to their distance. A similar feature holds in economics if we replace attraction with trade flows and use GDP as a measure of economic mass. Not surprisingly, it was a physicist (Nobel laureate Jan Tinbergen, 1962) who first used Newton's second law to explain international trade flows. Many researchers since then have confirmed this empirical regularity in economics, which yields a solid empirical explanation of bilateral trade flows and thus illustrates the regularity of interaction between economic centers quite effectively.

the data for 1996 in view of missing observations for the year 1997. 
Table 6 Estimated gravity equation, 1996

\begin{tabular}{|c|c|c|c|c|c|c|c|}
\hline & Africa & income & t-stat & distance & t-stat & adj. R2 & \# obs. \\
\hline$\overline{1}$ & South Africa & 0.957 & 11.87 & -2.886 & -7.39 & 0.67 & 129 \\
\hline 2 & Algeria & 0.194 & 1.35 & -1.256 & -3.57 & 0.16 & 53 \\
\hline 3 & Morocco & 0.552 & 6.63 & -1.860 & -6.48 & 0.40 & 99 \\
\hline 4 & Tunisia & 0.471 & 5.43 & -1.698 & -6.84 & 0.39 & 93 \\
\hline 5 & Egypt & 0.519 & 6.41 & -1.771 & -8.02 & 0.51 & 104 \\
\hline 6 & Cameroon & 0.600 & 4.67 & -2.873 & -8.34 & 0.41 & 70 \\
\hline 7 & Gabon & 0.680 & 4.40 & -2.009 & -4.96 & 0.28 & 64 \\
\hline 8 & Congo (Zaire) & 0.500 & 2.05 & -1.171 & -1.77 & 0.12 & 53 \\
\hline 9 & Ethiopia & 0.483 & 2.86 & -1.047 & -2.12 & 0.17 & 55 \\
\hline 10 & Ghana & 0.824 & 4.04 & -1.399 & -3.18 & 0.30 & 57 \\
\hline 11 & Cote D'ivoire & 0.528 & 4.43 & -2.167 & -5.31 & 0.38 & 58 \\
\hline 12 & Kenya & 0.497 & 4.78 & -2.199 & -7.24 & 0.29 & 94 \\
\hline 13 & Madagascar & 0.529 & 3.51 & -0.792 & -1.10 & 0.16 & 73 \\
\hline 14 & Malawi & 0.516 & 4.99 & -1.490 & -4.18 & 0.28 & 58 \\
\hline 15 & Mauritius & 0.500 & 4.50 & -1.448 & -2.44 & 0.17 & 80 \\
\hline 16 & Nigeria & 0.666 & 4.27 & -1.325 & -2.68 & 0.27 & 67 \\
\hline 17 & Senegal & 0.559 & 4.26 & -1.647 & -2.64 & 0.23 & 50 \\
\hline 18 & Zimbabwe & 0.820 & 6.41 & -2.239 & -6.44 & 0.42 & 90 \\
\hline 19 & Untd Rp Tanzania & 0.618 & 3.47 & -1.221 & -2.08 & 0.22 & 59 \\
\hline & North America & & & & & & \\
\hline 20 & Canada & 0.673 & 9.60 & -0.946 & -2.44 & 0.58 & 132 \\
\hline 21 & USA & 0.345 & 6.79 & -0.749 & -3.42 & 0.39 & 133 \\
\hline & South America & & & & & & \\
\hline 22 & Argentina & 0.821 & 11.12 & -1.612 & -5.90 & 0.51 & 119 \\
\hline 23 & Bolivia & 0.785 & 3.64 & -2.341 & -7.01 & 0.45 & 60 \\
\hline 24 & Brazil & 0.564 & 9.02 & -2.037 & -7.74 & 0.47 & 125 \\
\hline 25 & Chile & 0.761 & 10.44 & -2.394 & -7.81 & 0.55 & 111 \\
\hline 26 & Colombia & 0.661 & 7.71 & -1.901 & -10.43 & 0.51 & 101 \\
\hline 27 & Ecuador & 0.553 & 4.53 & -1.608 & -7.04 & 0.37 & 80 \\
\hline 28 & Mexico & 0.609 & 8.83 & -1.892 & -10.53 & 0.56 & 113 \\
\hline 29 & Peru & 0.955 & 7.95 & -1.935 & -6.28 & 0.50 & 97 \\
\hline 30 & Uruguay & 0.831 & 7.11 & -1.560 & -4.62 & 0.49 & 88 \\
\hline
\end{tabular}


Table 6 continued

\begin{tabular}{|c|c|c|c|c|c|c|c|}
\hline & & income & t-stat & distance & t-stat & adj. R2 & \# obs. \\
\hline 31 & Venezuela & 0.615 & 4.85 & -2.744 & -9.81 & 0.46 & 77 \\
\hline 32 & Costa Rica & 0.491 & 5.12 & -2.155 & -11.11 & 0.51 & 88 \\
\hline 33 & El Salvador & 0.595 & 5.52 & -1.992 & -9.96 & 0.52 & 50 \\
\hline 34 & Guatemala & 0.414 & 3.24 & -1.828 & -8.77 & 0.41 & 78 \\
\hline 35 & Honduras & 0.579 & 6.08 & -1.756 & -10.58 & 0.47 & 60 \\
\hline 36 & Nicaragua & 0.518 & 3.00 & -1.732 & -5.74 & 0.32 & 51 \\
\hline 37 & Bahamas & 0.519 & 3.14 & -0.340 & -1.01 & 0.18 & 62 \\
\hline 38 & Barbados & -0.000 & -0.00 & -1.165 & -3.12 & 0.12 & 51 \\
\hline 39 & Dominican Rp & 0.368 & 2.39 & -1.608 & -5.28 & 0.27 & 65 \\
\hline 40 & Jamaica & -0.007 & -0.04 & -1.217 & -2.99 & 0.15 & 58 \\
\hline 41 & Neth Antilles & 0.343 & 1.75 & -1.701 & -5.97 & 0.28 & 65 \\
\hline 42 & Trinidad-Tobago & 0.380 & 2.15 & -2.146 & -7.47 & 0.31 & 68 \\
\hline 43 & Panama & 0.319 & 3.04 & -1.433 & -6.61 & 0.32 & 61 \\
\hline & Middle East & & & & & & \\
\hline 44 & Israel & 0.657 & 10.72 & -0.531 & -3.10 & 0.53 & 111 \\
\hline 45 & Japan & 0.398 & 8.40 & -0.276 & -1.34 & 0.42 & 133 \\
\hline 46 & Bahrain & 0.522 & 5.88 & -1.565 & -7.66 & 0.36 & 68 \\
\hline 47 & Cyprus & 0.667 & 9.28 & -1.613 & -8.56 & 0.59 & 103 \\
\hline 48 & Iran & 0.508 & 3.27 & -1.651 & -5.24 & 0.41 & 71 \\
\hline 49 & Jordan & 0.588 & 4.52 & -1.224 & -3.36 & 0.36 & 62 \\
\hline 50 & Kuwait & 0.645 & 7.20 & -1.980 & -7.97 & 0.49 & 78 \\
\hline 51 & Lebanon & 0.489 & 4.16 & -1.264 & -6.10 & 0.36 & 66 \\
\hline 52 & Oman & 0.205 & 1.81 & -1.498 & -4.11 & 0.15 & 81 \\
\hline 53 & Saudi Arabia & 0.636 & 4.49 & -1.579 & -5.40 & 0.43 & 70 \\
\hline 54 & Syrn Arab Rp & 0.481 & 4.69 & -1.734 & -6.51 & 0.45 & 67 \\
\hline 55 & Untd Arab Em & 0.508 & 3.68 & -2.218 & -4.36 & 0.33 & 73 \\
\hline 56 & Turkey & 0.578 & 9.21 & -1.214 & -9.52 & 0.62 & 125 \\
\hline & Asia & & & & & & \\
\hline 57 & Afghanistan & 0.366 & 2.77 & -0.508 & -1.45 & 0.12 & 53 \\
\hline 58 & Bangladesh & 0.771 & 8.79 & -0.234 & -0.96 & 0.44 & 102 \\
\hline 59 & Myanmar (Burma) & 0.599 & 2.86 & -1.824 & -3.48 & 0.32 & 52 \\
\hline 60 & Sri Lanka & 0.597 & 6.08 & -1.843 & -5.18 & 0.50 & 79 \\
\hline
\end{tabular}


Table 6 continued

\begin{tabular}{|c|c|c|c|c|c|c|c|}
\hline & & income & t-stat & distance & t-stat & adj. R2 & \# obs. \\
\hline$\overline{61}$ & Hong Kong & 0.199 & 5.01 & -0.078 & \begin{tabular}{|c|}
-0.44 \\
\end{tabular} & 0.17 & 131 \\
\hline 62 & India & 0.381 & 7.22 & -0.756 & -4.24 & 0.34 & 132 \\
\hline 63 & Indonesia & 0.439 & 8.61 & -1.119 & -4.75 & 0.44 & 114 \\
\hline 64 & Malaysia & 0.406 & 7.27 & -1.083 & -6.80 & 0.39 & 129 \\
\hline 65 & Pakistan & 0.444 & 6.83 & -1.079 & -4.24 & 0.38 & 128 \\
\hline 66 & Philippines & 0.723 & 8.05 & -1.568 & -6.49 & 0.52 & 109 \\
\hline 67 & Singapore & 0.306 & 4.86 & -1.118 & -3.91 & 0.38 & 107 \\
\hline 68 & Taiwan & 0.308 & 3.55 & 0.041 & 0.22 & 0.17 & 83 \\
\hline 69 & China & 0.402 & 7.49 & -0.413 & -1.31 & 0.39 & 133 \\
\hline \multirow[t]{2}{*}{70} & Vietnam & 0.829 & 5.25 & -1.062 & -2.40 & 0.46 & 72 \\
\hline & Western Europe & & & & & & \\
\hline 71 & Belgium-Lux. & 0.383 & 7.05 & -0.371 & -2.83 & 0.41 & 133 \\
\hline 72 & Denmark & 0.447 & 7.74 & -0.723 & -5.40 & 0.56 & 133 \\
\hline 73 & France & 0.263 & 5.22 & -0.228 & -2.19 & 0.27 & 133 \\
\hline 74 & Germany & 0.274 & 6.99 & -0.367 & -3.76 & 0.47 & 133 \\
\hline 75 & Greece & 0.706 & 10.14 & -1.278 & -6.35 & 0.53 & 127 \\
\hline 76 & Ireland & 0.539 & 10.03 & -0.495 & -3.13 & 0.58 & 131 \\
\hline 77 & Italy & 0.280 & 7.29 & -0.305 & -3.70 & 0.44 & 133 \\
\hline 78 & Netherlands & 0.406 & 6.97 & -0.373 & -2.48 & 0.46 & 133 \\
\hline 79 & Portugal & 0.599 & 9.03 & -0.960 & -4.76 & 0.51 & 128 \\
\hline 80 & Spain & 0.419 & 7.99 & -0.269 & -2.24 & 0.40 & 129 \\
\hline 81 & United Kingdom & 0.227 & 5.90 & -0.175 & -2.18 & 0.24 & 133 \\
\hline 82 & Austria & 0.705 & 10.63 & -0.806 & -6.53 & 0.68 & 129 \\
\hline 83 & Finland & 0.609 & 10.24 & -0.933 & -5.28 & 0.61 & 126 \\
\hline 84 & Iceland & 0.547 & 4.10 & -1.708 & -3.82 & 0.40 & 63 \\
\hline 85 & Norway & 0.655 & 8.73 & -0.615 & -3.34 & 0.54 & 131 \\
\hline 86 & Sweden & 0.477 & 7.43 & -0.402 & -3.31 & 0.47 & 133 \\
\hline 87 & Switzerland & 0.541 & 8.15 & -0.239 & -1.49 & 0.48 & 133 \\
\hline \multirow[t]{2}{*}{88} & Malta & 0.499 & 5.83 & -1.019 & -4.34 & 0.33 & 88 \\
\hline & Eastern Europe & & & & & & \\
\hline 89 & Bulgaria & 0.639 & 5.95 & -1.366 & -8.17 & 0.60 & 74 \\
\hline 90 & Czechoslovakia & 0.592 & 8.43 & -0.938 & -5.73 & 0.54 & 128 \\
\hline
\end{tabular}


Table 6 continued

\begin{tabular}{ll|rr|rr|rr}
\hline \hline & income & t-stat & distance & t-stat & adj. R2 & \# obs. \\
\hline 91 Hungary & 0.686 & 9.25 & -1.164 & -6.98 & 0.60 & 119 \\
92 & Poland & 0.782 & 9.20 & -0.932 & -4.61 & 0.66 & 115 \\
93 & Romania & 0.606 & 7.82 & -1.584 & -8.62 & 0.51 & 120 \\
94 & Fm USSR & 0.598 & 6.35 & -1.563 & -7.50 & 0.52 & 109 \\
\hline & Oceania & & & & & & \\
95 & Australia & 0.727 & 10.07 & -2.802 & -7.20 & 0.56 & 132 \\
96 & New Zealand & 0.631 & 6.54 & -2.696 & -5.66 & 0.40 & 109
\end{tabular}

As an illustration of the regularity of the interaction between countries, Table 6 reports estimation results of a basic gravity equation for 96 countries in the world with at least 50 observations in 1996. The income data are from the World Development Indicators CD-ROM (2002; GNI, current dollars). The distances were determined using longitude and latitude data from the Britannica Atlas of the most important economic center in a country (usually the capital city) by calculating the distance to other economic centers using the assumption that the earth is a perfect sphere. ${ }^{13}$ The estimated equation is:

$$
\ln (\text { export })=\text { constant }+ \text { coefficient } 1 \times \ln (\text { GDP })+\text { coefficient }_{2} \times \ln (\text { distance })
$$

Except for Barbados and Jamaica, the estimated income coefficient has the right sign and is highly significant. ${ }^{14}$ The estimated significant coefficients are fairly close together, ranging from 0.194 for Algeria to 0.957 for South Africa, with an average of 0.545, a median of 0.544 , and a variance of only 0.027 . For all countries except Taiwan, the distance variable has the correct sign. The estimated coefficient is usually statistically (highly) significant, ranging from -2.886 for South Africa to -0.078 for Hong Kong. De average distance estimate is -1.354 , the median is -1.399 , and the variance is 0.486 .

Conclusion: There is a remarkable regularity in the interaction between economic centers. As it is proportional to the (economic) mass of a country and inversely related to the distance between countries, this is known as the 'gravity equation'.

\footnotetext{
${ }^{13}$ For the USA the shortest distance to either New York or Los Angeles was taken.

14 The calculated t-values are consistent under heteroscedasticity (White, 1980).
} 


\section{Summary and conclusions}

There is an enormous array of possibilities to analyze regarding economic concentration in terms of what (population, value added, specific sectors), where (global regions, countries, regions, districts, cities), and how (structure in spreading and interaction). At the global regional level as identified by the World Bank, economic activity is unevenly distributed. The relative density differences (highest density / lowest density) are large regarding population density (more than 14 times), GNP density (more than 62 times), and GNP density corrected for purchasing power differences (more than 18 times). At a lower level of geographic aggregation (the country level) the uneven distribution of economic activity becomes more pronounced, both for population and production (measured as value added, after correcting for purchasing power). A 'fractal dimension' in the distribution of economic activity becomes evident after establishing that at the regional and city level economic activity is also unevenly distributed. This enables the identification of core - periphery patterns at the regional level.

There are remarkable regularities in the distribution of economic activity, both with respect to the spatial distribution itself and regarding the interaction between economic centers. The degree of urbanization, which varies from country to country, is still increasing worldwide. There is a fractal dimension in the regularity of the spatial distribution of economic activity, known as the rank-size rule (with Zipf's Law as a special case), since this empirical regularity holds globally, at the continent level, and at the country level. The regularity in the interaction between economic centers, which is proportional to the (economic) mass of a country and inversely related to the distance between countries, is known as the gravity equation.

In short, we can summarize the distribution of economic activity in five stylized facts:

- There is an uneven distribution regardless of the type of economic activity.

- There is an uneven distribution regardless of the geographic level of aggregation.

- There is an uneven distribution regardless of the economic level of aggregation.

- There is a remarkable regula rity in the spatial distribution of economic activity.

- There is a remarkable regularity in the interaction between economic centers. 


\section{References}

Balassa, B. (1965), "Trade liberalization and "revealed" comparative advantage," Manchester School of Economic and Social Studies 33: 92-123.

Brakman, S., and H. Garretsen, eds. (2005), Location and competition, Routledge, London.

Brakman, S., H. Garretsen en C. van Marrewijk (2001), An introduction to geographical economics, Cambridge University Press, Cambridge, U.K.

Copus, A.K. (1999), "A new peripherality index for the NUTS III regions of the European Union," ERDF/FEDER Study 98/00/27/130, A Report for the European Commission, Directorate General XVI.A.4 (Regional Policy and Cohesion).

Fujita, M., P.R. Krugman en A.J. Venables (1999), The spatial economy: cities, regions, and international trade, MIT Press, Cambridge, MA.

Harris (1954), "The market as a factor in the localization of industry in the United States," Annals of the Association of American Geographers, 64: 315-348.

Hinloopen, J. en C. van Marrewijk (2001), "On the empirical distribution of the Balassa Index, Weltwirtschaftliches Archiv, 137: 1-35.

Keeble, D., P.L. Owens, en C. Thompson (1981), The influence of peripheral and central locations on the relative development of regions, Department of Geography, Cambridge University.

Marrewijk, C. van (2002), International trade \& the world economy, Oxford University Press, Oxford, U.K.

Quigley, J.M. (1998), "Urban diversity and economic growth," Journal of Economic Perspectives, vol. 12, no. 2: 127-138.

Rivera-Batiz, F.L, en L.A. Rivera-Batiz (1998), “Agglomeration externalities, geography, and the labor market: theory and evidence," article presented at the Trade, Location, and Technology Conference, sponsored by the Centre for Economic Policy Research (CEPR).

Soo, Kwok Tong (2002), “Zipf's Law for citie s: a cross country investigation,” mimeo, London School of Economics.

Tinbergen, J. (1962), Shaping the World Economy, Twentieth Century Fund, New York.

World Bank (2000), World Development Report 1999, Washington DC.

White, H. (1980), "Nonlinear regression on cross-section data," Econometrica, vol 48, no. 3, 721-746.

Zipf, G.K. (1949), Human behavior and the principle of least effort, Addison-Wesley, New York. 
Appendix World Bank global regions, 2002

East Asia \& Pacific $(E A P)$, excluding high-income economies

$\begin{array}{lll}\text { American Samoa } & \text { Cambodia } & \text { China } \\ \text { Fiji } & \text { Indonesia } & \text { Kiribati } \\ \text { Korea, Dem. Rep. } & \text { Korea, Rep. } & \text { Lao PDR } \\ \text { Malaysia } & \text { Marshall Islands } & \text { Micronesia, Fed. Sts. } \\ \text { Mongolia } & \text { Myanmar } & \text { Palau } \\ \text { Papua New Guinea } & \text { Philippines } & \text { Samoa } \\ \text { Solomon Islands } & \text { Thailand } & \text { Tonga } \\ \text { Vanuatu } & \text { Vietnam } & \end{array}$

Europe \& Central Asia (ECA), excluding high-income economies

$\begin{array}{lll}\text { Albania } & \text { Armenia } & \text { Azerbaijan } \\ \text { Belarus } & \text { Bosnia \& Herzegovina } & \text { Bulgaria } \\ \text { Croatia } & \text { Czech Republic } & \text { Estonia } \\ \text { Georgia } & \text { Hungary } & \text { Isle of Man } \\ \text { Kazakhstan } & \text { Kyrgyz Republic } & \text { Latvia } \\ \text { Lithuania } & \text { Macedonia, FYR } & \text { Moldova } \\ \text { Poland } & \text { Romania } & \text { Russian Federation } \\ \text { Slovak Republic } & \text { Tajikistan } & \text { Turkey } \\ \text { Turkmenistan } & \text { Ukraine } & \text { Uzbekistan }\end{array}$

Yugoslavia, Fed. Rep.

High income $(H I C)$ group aggregate (2000 GNI per capita of $\$ 9,266$ or more)

$\begin{array}{lll}\text { Andorra } & \text { Aruba } & \text { Australia } \\ \text { Austria } & \text { Bahamas, The } & \text { Barbados } \\ \text { Belgium } & \text { Bermuda } & \text { Brunei } \\ \text { Canada } & \text { Cayman Islands } & \text { Channel Islands } \\ \text { Cyprus } & \text { Denmark } & \text { Faeroe Islands } \\ \text { Finland } & \text { France } & \text { French Polynesia } \\ \text { Germany } & \text { Greece } & \text { Greenland } \\ \text { Guam } & \text { Hong Kong, China } & \text { Iceland } \\ \text { Ireland } & \text { Israel } & \text { Italy } \\ \text { Japan } & \text { Kuwait } & \text { Liechtenstein }\end{array}$




$\begin{array}{lll}\text { Luxembourg } & \text { Macao, China } & \text { Malta } \\ \text { Monaco } & \text { Netherlands } & \text { Netherlands Antilles } \\ \text { New Caledonia } & \text { New Zealand } & \text { N. Mariana Islands } \\ \text { Norway } & \text { Portugal } & \text { Qatar } \\ \text { San Marino } & \text { Singapore } & \text { Slovenia } \\ \text { Spain } & \text { Sweden } & \text { Switzerland } \\ \text { United Arab Emirates } & \text { United Kingdom } & \text { United States } \\ \text { Virgin Islands (U.S.) } & & \\ & & \\ \text { Latin America \& Caribbean } & \text { LAC), excluding high-income economies } \\ \text { Antigua and Barbuda } & \text { Argentina } & \text { Belize } \\ \text { Bolivia } & \text { Brazil } & \text { Chile } \\ \text { Colombia } & \text { Costa Rica } & \text { Cuba } \\ \text { Dominica } & \text { Dominican Republic } & \text { Ecuador } \\ \text { El Salvador } & \text { Grenada } & \text { Guadeloupe } \\ \text { Guatemala } & \text { Guyana } & \text { Haiti } \\ \text { Honduras } & \text { Jamaica } & \text { Mexico } \\ \text { Nicaragua } & \text { Panama } & \text { Paraguay } \\ \text { Peru } & \text { Puerto Rico } & \text { St. Kitts and Nevis } \\ \text { St. Lucia } & \text { St. Vincent \& Grenad. } & \text { Suriname } \\ \text { Trinidad and Tobago } & \text { Uruguay } & \text { Venezuela, RB }\end{array}$

Middle East \& North Africa (MNA), excluding high-income economies

\begin{tabular}{|c|c|c|}
\hline Algeria & Bahrain & Djibouti \\
\hline Egypt, Arab Rep. & Iran, Islamic Rep. & Iraq \\
\hline Jordan & Lebanon & Libya \\
\hline Morocco & Oman & Saudi Ar \\
\hline Syrian Arab Republic & Tunisia & West Ba \\
\hline \multicolumn{3}{|l|}{ Yemen, Rep. } \\
\hline \multicolumn{3}{|l|}{ South Asia $(S A S)$} \\
\hline Afghanistan & Bangladesh & Bhutan \\
\hline India & Maldives & Nepal \\
\hline Pakistan & Sri Lanka & \\
\hline
\end{tabular}


$\underline{\text { Sub-Saharan Africa }}$ (SSA)

$\begin{array}{lll}\text { Angola } & \text { Benin } & \text { Botswana } \\ \text { Burkina Faso } & \text { Burundi } & \text { Cameroon } \\ \text { Cape Verde } & \text { Central African Rep. } & \text { Chad } \\ \text { Comoros } & \text { Congo, Dem. Rep. } & \text { Congo, Rep. } \\ \text { Côte d'Ivoire } & \text { Equatorial Guinea } & \text { Eritrea } \\ \text { Ethiopia } & \text { Gabon } & \text { Gambia, The } \\ \text { Ghana } & \text { Guinea } & \text { Guinea-Bissau } \\ \text { Kenya } & \text { Lesotho } & \text { Liberia } \\ \text { Madagascar } & \text { Malawi } & \text { Mali } \\ \text { Mauritania } & \text { Mauritius } & \text { Mayotte } \\ \text { Mozambique } & \text { Namibia } & \text { Niger } \\ \text { Nigeria } & \text { Rwanda } & \text { São Tomé \& Principe } \\ \text { Senegal } & \text { Seychelles } & \text { Sierra Leone } \\ \text { Somalia } & \text { South Africa } & \text { Sudan } \\ \text { Swaziland } & \text { Tanzania } & \text { Togo } \\ \text { Uganda } & \text { Zambia } & \text { Zimbabwe }\end{array}$

